\title{
THE EFFECT OF HUMAN RESOURCES DEVELOPMENTAND WORK ABILITY ON EMPLOYEE PERFORMANCE IN THE DEPARTMENT OF HOUSING AND SETTLEMENTS AREA OF KAUR REGENCY
}

\section{PENGARUH PENGEMBANGAN SDM DAN KEMAMPUAN KERJA TERHADAP PRESTASI KERJA PEGAWAI PADA DINAS PERUMAHAN DAN KAWASAN PERMUKIMAN KABUPATEN KAUR}

\author{
Merwan Afrizal1);Ahmad Soleh ${ }^{2}$ ); Meiffa Herfianti ${ }^{3)}$ \\ ${ }^{1)}$ Study Program of Management, Faculty of Economic, Universitas Dehasen \\ Bengkulu \\ 2) Department of Accounting, Faculty of Economic, Universitas Dehasen Bengkulu \\ 3) Department of Management, Faculty of Economic, Universitas Dehasen Bengkulu
}

Email: 2)ahmadsolehse81@yahoo.co.id

\section{ARTICLE HISTORY}

Received [21 July 2020]

Revised [12 November 2020]

Accepted [14 December 2020]

\section{KEYWORDS}

HR Development, Work Ability, Job Performance

This is an open access article under the $C C-B Y$-SA licenced

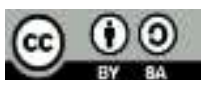

\begin{abstract}
ABSTRAK
Penelitian ini bertujuan untuk menganalisis pengaruh pengembangan SDM dan kemampuan kerjaterhadap prestasi kerja pegawai pada Dinas Perumahan dan Kawasan Permukiman Kabupaten Kaur. Metode pengumpulan data dengan membagikan kuesioner kepada 43 orang pegawai. Analisis data yang digunakan adalah analisis kuantitatif, dengan metode regresi linier berganda, uji determinasi, uji t dan uji F. Hasil penelitian menunjukkan bahwapengembangan SDM dan kemampuan kerja berpengaruh positif dan signifikan secara parsial dan simultan terhadapprestasi kerja pegawai pada Dinas Perumahan dan Kawasan Permukiman Kabupaten Kaur.
\end{abstract}

\begin{abstract}
This study aims to analyze the effect of human resource development and work ability on employee performance in the Department of Housing and Settlements Area of Kaur Regency. Data collection method is by distributing questionnaires to 43 employees. Data analysis used was quantitative analysis, with multiple linear regression methods, determination test, $t$ test and $F$ test. The results showed that the development of human resources and work ability had a positive and significant effect simultaneously on employee performance in the Department of Housing and Settlement Areas of Kaur Regency.
\end{abstract}




\section{PENDAHULUAN}

Era persaingan global menuntut kompetensi yang kini telah menjadi bahan telaah demi pengembangan sumber daya suatu perusahaan, institusi maupun organisasi. Sumber Daya Manusia (SDM) menjadi aset penting organisasi manapun untuk mencapai keunggulan kompetitif di era globalisasi. Salah satu elemen yang penting untuk dikembangkan dalam sebuah organisasi adalah pengembangan SDM yang dilakukan secara dinamis (Dewi \& Bendriyanti, 2019). Pengembangan sumber daya manusia adalah fungsi organisasi yang berfokus pada rekrutmen, pengelolaan dan navigasi bagi karyawan dalam bekerja pada suatu organisasi yang diwujudkan melalui sinergi untuk memperkuat mutualitas menuju tujuan bersama (Labola, 2019).SDM memiliki peran aktif dan dominan dalam setiap organisasi, karena SDM merupakan perencana, pelaku, dan penentu terwujudnya tujuan organisasi Suwatno\& Priansa (2011).

Organisasi pemerintah yang terdiri atasi multi fungsi pegawai atau aparatur pemerintah sebagai sumber daya manusia, memiliki arti dan peran penentu dalam mencapai tujuan dan sasaran keseluruhan tugas pemerintahan.Pengembangan SDM sangat penting bagi organisasi pemerintah.Sebagai organisasi publik yang berfungsi memberikan pelayanan kepada masyarakat dalam berbagai bidang bagi peningkatan kehidupan dan kesejahteraan masyarakat. Pengembangan SDM dapat dilakukan melalui pendidikan dan pelatihan sehingga dapat meningkatkan kinerja karyawan (Sutrisno, 2009).

Selain pengembangan SDM dalam peningkatan layanan kepada masyarakat, faktor kemampuan kerja bagi Pegawai Negeri Sipil juga menjadi aspek yang sangat penting. Menurut Hasibuan (2015) kemampuan kerja adalah suatu hasil kerja yang dicapai seseorang dalam melaksanakan tugas-tugas yang dibebankan kepadanya yang didasarkan atas kecakapan, pengalaman dan kesungguhan serta waktu. Mangkunegara (2016) menjelaskan kemampuan adalah satu keadaan dimana seseorang siap menghadapi segala sesuatu dengan bekerja dan resiko yang harus diterima. Sedangkan Robbins (2014) mendefinisikan bahwa kemampuan adalah suatu kapasitas individu untuk mengerjakan berbagai tugas dalam suatu pekerjaan.

Prestasi kerja merupakan hasil kerja secara kualitas dan kuantitas yang dicapai oleh seorang pegawai dalam melaksanakan tugasnya sesuai dengan tanggung jawab yang diberikannya (Mangkunegara, 2016). Pihak manajemen suatu instansi harus berusaha mendorong pegawainya untuk bekerja dengan baik sehingga dapat mencapai prestasi yang terbaik. Untuk menciptakan prestasi pegawai tentu saja ada beberapa hal yang harus diperhatikan oleh instansi, seperti pengembangan sumber daya manusia dan kemampuan kerja. Dinas Perumahan dan Kawasan Permukiman Kabupaten Kaur merupakan Dinas di bawah pengawasan Dinas Pekerjaan Umum yang memiliki bidang pekerjaan khususnya pada pemukiman dan perumahan. Mengingat prestasi kerja pegawai sangat penting dalam menunjang keberhasilan organisasi, pegawai harus mampu melaksanakan tugas dan kewajibanya secara tepat waktu dan memuaskan, sesuai tujuan yang diharapkan.

Studi literatur menunjukkan bahwa terdapat beberapa penelitian sebelumnya yang menemukan bahwa pengembangan SDM memiliki pengaruh positif dan signifikan terhadap prestasi kerja(Krisdianto \& Nurhayati, 2017; Nugraha, 2016; Sutrisno, 2006; Tarigan, 2014; dan Yusran, 2018).Namun, terdapat studi yang memenukan bahwa pengembangan SDM tidak memiliki pengaruh terhadap prestasi kerja (Karo-Karo, 2016; dan Saragi, 2018). Selanjutnya, studi literatur tentang kemampuan kerja ditemukan memiliki pengaruh positif dan signifikan terhadap 
prestasi kerja (Afifi, dkk. 2015; Herawati \& Arsilenda, 2015; Susetyorini, 2012; Wijayanto \& Suhendar, 2016; dan Yanti, dkk. 2019). Temuan tersebut berbeda dengan hasil penelitian yang dilakukan oleh Normajatun \& Haliq (2016) yang mengkonfirmasi bahwa kemampuan kerja tidak berpengaruh terhadap prestasi kerja.

Berdasarkan permasalahan dan terdapat kesenjangan hasil penelitian sebelumnya antara pengembangan SDM dan kemampuan kerja terhadap prestasi kerja, maka penelitian ini akan mengklarifikasi kesenjangan tersebut, sehingga dapat memberikan kontribusi bagi instansi untuk menjadi bahan pertimbangan dalam mengembangkan strategi pencapaian prestasi kerja. Dengan demikian tujuan dari peneltian ini adalah untuk menganalisis pengaruh pengembangan Sumber Daya Manusia dankemampuan kerja terhadap prestasi kerja pergawai pada Dinas Perumahan dan Kawasan Permukiman Kabupaten kaur.

\section{LANDASAN TEORI}

\section{Pengembangan Sumber Daya Manusia}

Pengembangan sumber daya manusia jangka panjang sebagai pembeda dari kegiatan pelatihan untuk pekerjaan tertentu telah menjadi perhatian dari pengembangan sumber daya manusia. Melalui kegiatan pengembangan karyawan yang ada, pengembangan sumber daya manusia berusaha mengurangi ketergantungan perusahaan terhadap pengangkatan karyawan baru. Jika karyawan dikembangkan secara tepat, lowongan formasi, melalui kegiatan perencanaan sumber daya manusia, akan dapat diisi secara internal. Pengembangan (development) menurut Prawirosentono (2013) adalah suatu investasi yang berorientasi ke masa depan dalam diri pegawai. Pengembangan didasarkan pada kenyataan bahwa seorang pegawai akan membutuhkan serangkaian pengetahuan, kehalian dan kemampuan yang berkembang supaya bekerja dengan baik dan suksesi posisi yang ditemui selama karirnya. Rachmawati (2015) mengemukakan pengembangan adalah didasarkan pada fakta bahwa karyawan akan membutuhkan pengetahuan, keahlian, dan kemampuan yang berkembang untuk bekerja dengan lebih baik dalam suksesi yang ada dalam rekrutmen.

Martoyo (2017) mengemukakan bahwa pengembangan bertujuan untuk menyiapkan pegawainya siap memangku jabatan tertentu di masa yang akan datang. Pengembangan bersifat lebih luas karena menyangkut banyak aspek seperti peningkatan dalam keilmuan, pengetahuan, kemampuan, sikap, dan kepribadian.Silalahi (2015) mengemukakan bahwa pengembangan sumber daya manusia adalah upaya berkesinambungan meningkatkan mutu sumber daya manusia dalam arti yang seluas-luasnya, melalui pendidikan, latihan, dan pembinaan.Pengembangan sumber daya manusia juga merupakan cara yang efektif untuk menghadapi beberapa tantangan, termasuk keusangan atau ketertinggalan karyawan, diversifikasi tenaga kerja domestik dan internasional. Dengan dapat teratasinya tantangan-tantangan (affirmative action) dan turnover karyawan, pengembangan sumber daya manusia dapat menjaga atau mempertahankan tenaga kerja yang efektif.Menurut Tohardi (2014) indikator pengembangan sumber daya manusia adalah (1) produktivitas kerja; (2) efisiensi; (3) pelayanan; (4) moral; dan karir. 


\section{Kemampuan Kerja}

Kemampuan kerja menurut Hasibuan (2015) adalah suatu hasil kerja yang dicapai seseorang dalam melaksanakan tugas-tugas yang dibebankan kepadanya yang didasarkan atas kecakapan, pengalaman dan kesungguhan serta waktu. Menurut Mangkunegara (2016) kemampuan adalah satu keadaan dimana seseorang siap menghadapi segala sesuatu dengan bekerja dan resiko yang harus diterima. Selanjutnya, Robbins (2014) mendefinisikan bahwa kemampuan adalah suatu kapasitas individu untuk mengerjakan berbagai tugas dalam suatu pekerjaan. Selanjutnya totalitas kemampuan dari seseorang individu pada hakekatnya tersusun dari dua perangkat faktor, yakni kemampuan intelektual dan kemampuan fisik. Kemampuan intelektual adalah kemampuan untuk menjalankan kegiatan mental. Kemampuan fisik adalah kemampuan yang diperlukan untuk melakukan tugas-tugas yang menuntut stamina, kecekatan, kekuatan dan bakat-bakat sejenis.

MenurutDharma (2015) kemampuan seorang pegawai secara aplikatif indikatornya meliputi (1) keterampilan menjalankan tugas (skill duty); (2) keterampilan memberikan penguatan (reinforcement skill); dan (3) keterampilan mengadakan variasi (variation skill). Selanjutnya menurut Mangkunegara (2016), faktor-faktor yang mempengaruhi kemampuan adalah (1) Pengetahuan (kownledge) yaitu Informasi yang telah diproses dan diorganisasikan untuk memperoleh pemahaman, pembelajaran dan pengalaman yang terakumulasi sehingga bisa diaplikasikan ke dalam pekerjaan pegawai itu sendiri; dan (2) Keterampilan (skill) yaitu kemampuan pegawai untuk menyelesaikan pekerjaan dengan efektif dan efisien secara teknik pelaksanaan kerja tertentu yang berkaitan dengan tugas individu dalam suatu organisasi.

\section{Prestasi Kerja}

Menurut Sutrisno (2014), prestasi kerja adalah hasil upaya seseorang yang ditentukan oleh kemampuan karakteristik pribadinya serta persepsi terhadap perannya terhadap pekerjaan itu. Menurut Mangkunegara (2016), prestasi kerja adalah hasil kerja secara kualitas dan kuantitas yang dicapai oleh seorang pegawai dalam melaksanakan tugasnya sesuai dengan tanggung jawab yang diberikannya.Prestasi kerja adalah suatu hasil kerja yang dicapai seseorang dengan melaksanakan tugas yang dibebankan kepadanya yang didasarkan atas kecakapan, pengalaman, kesungguhan serta waktu (Hasibuan, 2015). Sedangkan menurut As'ad (2015), prestasi kerja adalah kualitas, kuantitas, waktu yang dipakai, jabatan yang dipegang, absensi, dan keselamatan dalam menjalankan pekerjaan.

Sutrisno (2014) mengatakan bahwa ada dua faktor yang mempengaruhi prestasi kerja, yaitu faktor individu dan faktor lingkungan. Sedangkan Mangkunegara (2016) mengatakan bahwa faktor-faktor yang mempengaruhi prestasi kerja adalah faktor kemampuan dan faktor etika kerja. Pekerjaan dengan hasil yang tinggi harus dicapai oleh pegawai. Nasution (2016) menyatakan bahwa indikator yang perlu diperhatikan dalam prestasi kerja adalah (1) kualitas kerja; (2) kuantitas kerja; (3) disiplin kerja; (4) inisiatif; dan (5) kerjasama.

Menurut Buchari (2016) beberapa indikator yang mempengaruhi tinggi rendahnya prestasi kerja yaitu:

1) Hubungan yang harmonis antara pimpinan dan bawahan terutama antar pimpinan kerja yang sehari-hari langsung berhubungan dengan para pekerja bawahan. 
2) Kepuasan para pekerja terhadap tugas dan pekerjaannya karena memperoleh tugas yang disukai sepenuhnya.

3) Terdapatnya suatu rencana dan iklim kerja yang bersahabat dengan anggotaanggota lainnya, organisasi apabila dengan mereka yang sehari-hari banyak berhubungan dengan pekerjaanya.

4) Rasa kemanfaatan bagi tercapainya tujuan organisasi yang juga merupakan tujuan bersama yang harus diwujudkan secara bersama-sama pula.

5) Adanya tingkat kepuasan ekonomi dan kepuasan-kepuasan internal lainnya yang memadai sebagai imbalan yang dirasakan adil terhadap jerih payah yang telah diberikan kepada organisasi.

6) Adanya ketenangan jiwa, kepastian serta perlindungan terhadap segala sesuatu yang dapat membahagiakan diri pribadi dan karier dalam pekerjaan

\section{Kerangka Analisis}

Menurut Sugiyono (2017), kerangaka analisis merupakan model konseptual tentang bagaimana teori berhubungan dengan berbagai faktor yang telah didefinisikan sebagai masalah yang penting. Pengembangan Sumber Daya Manusia dan kemampuan kerja menjadi hal yang sangat penting bagi tercapainya prestasi kerja. Sebagai alur hubungan antara variabel tersebut dalam penelitian ini seperti pada gambar 1.

Gambar 1. Kerangka Analisis

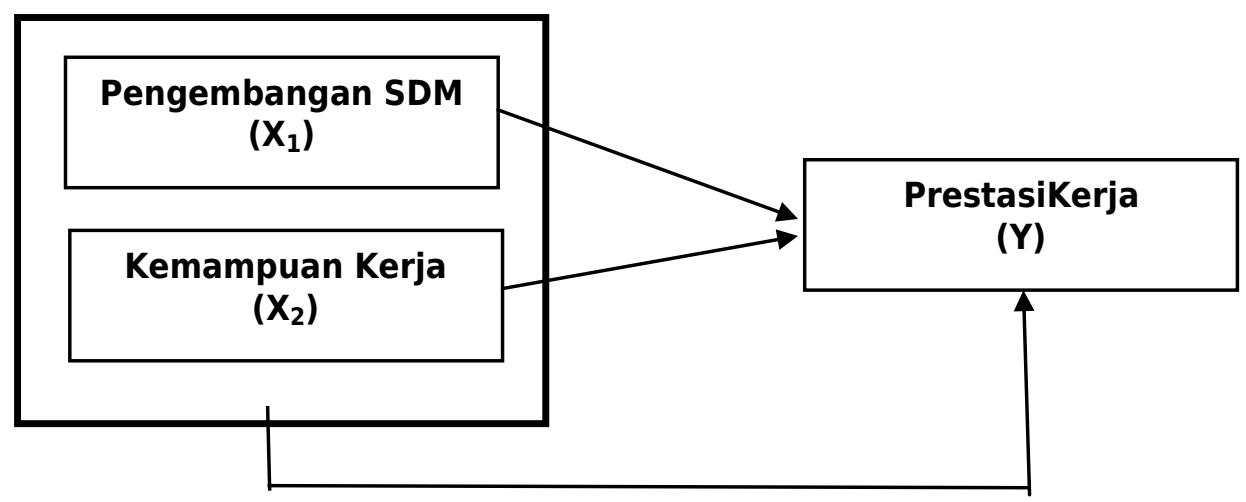

\section{METODE PENELITIAN}

\section{Metode Analisis}

Metode kuantitatif digunakan dalam penelitian ini. Pengujian hipotesis penelitian menggunakan metode regresi linier berganda. Analisis regresi linier berganda ini digunakan untuk mengetahui adakah pengaruh pengembangan SDM dan kemampuan kerja terhadap Prestasi Kerja 43 orangpegawai pada Dinas Perumahan dan Kawasan Permukiman Kabupaten Kaur. Persamaan untuk model Regresi Linier berganda : 


\section{$Y=\beta_{0}+\beta_{1} X_{1}+\beta_{2} X_{2}$}

Keterangan :

$\mathrm{Y}=$ Prestasi kerja

$\mathrm{B}_{0}=$ Konstanta

$\beta_{1}=$ Standar koefisien regresi linier dari pengambangan SDM

$\beta_{2}=$ Standar koefisien regresi linier dari kemampuan kerja

$\mathrm{X}_{1}=$ Pengambangan SDM

$\mathrm{X}_{2}=$ Kemampuan kerja

Untuk mengetahui seberapa besar pengaruh pengembangan SDM dan kemampuan kerja secara bersama-sama terhadap prestasi kerja pegawai pada Dinas Perumahan dan Kawasan Permukiman Kabupaten Kaur, maka digunakan Uji Determinasi, yaitu dengan cara menghitung koefisien determinasi $\left(R^{2}\right)$. Untuk mengetahui signifikansi pengaruh pengembangan SDM dan kemampuan kerjaterhadap prestasi kerja pegawai pada Dinas Perumahan dan Kawasan Permukiman Kabupaten Kaur, baik secara parsial maupun secara simultan, maka dilakukan pengujian hipotesis dengan menggunakan uji parsial (uji t) dan uji simultan (uji F atau Anova).

\section{HASIL DAN PEMBAHASAN}

\section{Hasil}

\section{Uji Validitas dan Reliabilitas}

Hasil uji validitas dengan menggunakan corelasion products moment menunjukkan bahwa atas30 butir pertanyaan yang diuji terhadap 43 pegawai, ternyata semua item pertanyaan sah (valid), sebab memiliki nilai korelasi besar dari 0,301 . Oleh karena itu, semua variabel dapat dijadikan sebagai indikator dalam penelitian ini. Selanjutnya untuk uji reliabilitas, hasil cronbach's alpha lebih besar dari 0,60 untuk kesemua variabel yaitu pengembangan SDMm kemampuan kerja dan prestasi kerja. Hasil uji reliabilitas dari masing-masing variabel ditunjukkan pada tabel 1.

Tabel 1. Hasil Uji Reliabilitas

\begin{tabular}{|l|c|c|}
\hline \multicolumn{1}{|c|}{ Variabel } & Cronbach's alpa & Keterangan \\
\hline Pengembangan SDM & 0,788 & Cronbach alpa> 0,6 (Reliabel) \\
\hline Kemampuan kerja & 0,750 & Cronbach alpa> 0,6(Reliabel) \\
\hline Prestasi kerja & 0,626 & Cronbach alpa> 0,6(Reliabel) \\
\hline
\end{tabular}

\section{Regresi Linier Berganda}

Berdasarkan hasil penyebaran kuesioner yang dilakukan terhadap 43 pegawai pada Dinas Perumahan dan Kawasan Permukiman Kabupaten Kaur,kemudian dilakukan pengolahan data menggunakan program SPSS for windows versi 16.0, maka diperoleh hasil I sebagaiberikut :

Tabel 2. Hasil Regresi Linier Berganda

\begin{tabular}{|c|c|c|c|c|c|c|}
\hline \multirow[b]{3}{*}{ Mode } & \multicolumn{6}{|c|}{ Coefficients $^{\mathrm{a}}$} \\
\hline & & \multicolumn{2}{|c|}{$\begin{array}{c}\text { Unstandardized } \\
\text { Coefficients }\end{array}$} & \multirow{2}{*}{$\begin{array}{c}\text { Standardized } \\
\text { Coefficients } \\
\text { Beta } \\
\end{array}$} & \multirow[b]{2}{*}{$\mathrm{t}$} & \multirow[b]{2}{*}{ Sig. } \\
\hline & & $\mathrm{B}$ & Std. Error & & & \\
\hline 1 & (Constant) & 1.919 & 5.403 & & .355 & .724 \\
\hline & Pengembangan SDM & .710 & .131 & .592 & 5.429 & .000 \\
\hline
\end{tabular}


Berdasar hasil perhitungan pada tabel 2 yang ditulis dalam bentuk unstandardized coefficients, maka dapat dibuat persamaan regresi linear berganda yaitu:

$$
Y=1,919+0,710 X_{1}+0,366 X_{2}
$$

Dari persamaan 2 regresi linier berganda dapat dijelaskan bahwa nilai konstanta 1,919 mempunyai arti bahwa apabila variabel pengembangan SDM $\left(\mathrm{X}_{1}\right)$ dan kemampuan kerja $\left(\mathrm{X}_{2}\right)$ dianggap sama dengan nol $(0)$ maka variabel prestasi kerja $(Y)$ akan tetap sebesar 1,919. Nilai koefesien regresi variabel $X_{1}$ (pengembanan SDM) adalah sebesar 0,710 dengan asumsi apabila $X_{1}$ (pengembangan SDM) mengalami peningkatan sebesar satu-satuan, maka $Y$ (prestasi kerja) juga akan mengalami peningkatan sebesar 0,710 kali. Selanjutnya, nilai koefesien regresi variabel $X_{2}$ (kemampuan kerja) adalah sebesar 0,366 dengan asumsi apabila $X_{2}$ (kemampuan kerja) mengalami peningkatan sebesar satu-satuan maka Y (prestasi kerja) juga akan mengalami peningkatan sebesar 0,366 kali.

\section{Uji Determinasi}

Uji determinasi dilakukan dengan cara menghitung koefisien determinasi $\left(R^{2}\right)$. Uji determinasi bertujuan untuk mengetahui seberapa besar variabel-variabel bebas (pengembangan SDM dan kemampuan kerja) memiliki pengaruh terhadap variabel terikatnya (prestasi kerja). Nilai koefisien determinasi ditunjukkan pada tabel 3.

Tabel 3. Koefisien Determinasi $\left(R^{2}\right)$

\begin{tabular}{|l|r|r|r|r|}
\hline & & & \multicolumn{1}{c|}{ Model Summary } \\
\hline Model & $R$ & R Square & \multicolumn{1}{c|}{ Square } & $\begin{array}{c}\text { Std. Error of the } \\
\text { Estimate }\end{array}$ \\
\hline 1 & $.788^{a}$ & .620 & .601 & 2.123 \\
\hline
\end{tabular}

a. Predictors: (Constant), Kemampuan Kerja, Pengembangan SDM

Berdasar tabel 3 diperoleh angka $\mathrm{R}^{2}$ ( $R$ Square) sebesar 0,620atau (62\%). Hal ini menunjukkan bahwa persentase sumbangan pengaruh pengembangan SDM dan kemampuan kerjaterhadap prestasi kerja pegawai pada Dinas Perumahan dan Kawasan Permukiman Kabupaten Kaur sebesar 62\%. Dengan kata lain variabel prestasi kerja dapat dijelaskan atau dipengaruhi oleh variabel pengembangan SDM 
dan kemampuan kerjasebesar 62\%, sedangkan sisanya 38\% dijelaskan atau dipengaruhi oleh variabel lain yang tidak diteliti.

\section{Pengujian Hipotesis Uji t}

Uji t dilakukan untuk menguji signifikansi koefisien regresi linier berganda secara parsial. Berdasarkan hasil uji t pada tabel 2, pengembangan SDM dan kemampuan kerja secara parsial memiliki pengaruh yang signifikan dengan prestasi kerja pegawai pada Dinas Perumahan dan Kawasan Permukiman Kabupaten Kaur. $\mathrm{Hal}$ ini dibuktikan dengan nilai probabilitas sig, $<0,05$. Untuk variabel $X_{1}$ (pengembangan SDM)menunjukkan nilai signifikansi sebesar 0,000 lebih kecil dari 0,05 . Demikian halnya variabel $X_{2}$ (kemampuan kerja)menunjukkan nilai sebesar 0,006 lebih kecil dari 0,05. Sehingga dapat disampaikan bahwa pengembangan SDM dan kemampuan kerja masing-masingberpengaruh signifikan terhadap prestasi kerja pegawai pada Dinas Perumahan dan Kawasan Permukiman Kabupaten Kaur, dengan demikian hipotesis awal yang diajukan dapat terbukti (Ha diterima).

\section{Uji F}

Uji F dilakukan untuk mengetahui apakah variabel bebas secara simultan memiliki pengaruh yang signifikan terhadap variabel terikat.Berdasarkan hasil uji $\mathrm{F}$ pada 4, menunjukkan signifikansi sebesar $0,000<0,05$. Karena tingkat signifikansi di bawah 0,05 dapat disampaikan bahwa variabel pengembangan SDM dan kemampuan kerjaberpengaruh signfikan secara bersama-sama terhadap prestasi kerjapegawai pada Dinas Perumahan dan Kawasan Permukiman Kabupaten Kaur, dengan demikian hipotesis awal yang diajukan terbukti (Ha diterima).

Tabel 4. Hasil Uji F (Anova)

\begin{tabular}{|ll|r|r|r|r|r|}
\hline \multicolumn{1}{|l|}{} & ANOVA $^{\mathrm{a}}$ \\
\hline 1 & Sum of Squares & \multicolumn{1}{|c|}{ df } & Mean Square & \multicolumn{1}{c|}{ F } & \multicolumn{1}{c|}{ Sig. } \\
\hline & Regression & 294.800 & 2 & 147.400 & 32.690 & $.000^{\circ}$ \\
& Residual & 180.363 & 40 & 4.509 & & \\
& Total & 475.163 & 42 & & & \\
\hline
\end{tabular}

a. Dependent Variable: Prestasi Kerja

b. Predictors: (Constant), Kemampuan Kerja, Pengembangan SDM

signifikan terhadap prestasi kerja pegawai pada Dinas Perumahan dan Kawasan Permukiman Kabupaten Kaur, karena nilai signifikan sebesar 0,000 kecil dari 0,05. $\mathrm{Hal}$ ini menggambarkan bahwa semakin meningkat pengembangan SDM maka prestasi kerja pegawai pada Dinas Perumahan dan Kawasan Permukiman Kabupaten Kaur juga akan semakin meningkat.

Hasil penelitian sejalan dengan teori yang disampaikan oleh Silalahi (2015) mengemukakan bahwa pengembangan sumber daya manusia adalah upaya berkesinambungan meningkatkan mutu sumber daya manusia dalam arti yang seluas-luasnya, melalui pendidikan, latihan, dan pembinaan. Pengembangan SDM dapat dilakukan dengan cara memberikan pelatihan kepada para pegawai seperti mengikuti berbagai macam seminar, mengikuti pelatihan-pelatihan yang diadakan

80 I P a g e Afrizal M, Soleh A, Herfianti M; The Effect Of Human Resources Development.... 
baik di tingkat Kabupaten maupun ditingkat Provinsi. Hasil penelitian ini juga sejalan dengan penelitian terdahulu yang dilakukan oleh Krisdianto \& Nurhayati (2017); Nugraha (2016) Sutrisno (2006); Tarigan (2014); dan Yusran (2018) bahwa pengembangan SDM memiliki pengaruh positif dan signifikan terhadap prestasi kerja.

Penelitian ini juga menunjukkan bahwa terdapat pengaruh yang signifikan antara kemampuan kerjaterhadap prestasi kerja, dengan nilai signfinikan sebesar 0,006 kecil dari 0,05. Hasil ini dapat diartikan bahwa apabila kemampuan kerja meningkat, maka prestasi kerja juga semakin meningkat. Apabila pegawai memiliki kemampuan kerja yang tinggi dalam menyelesaikan semua pekerjaan dan tanggung jawab yang diberikan kepadanya maka prestasi kerja pegawai dapat semakin meningkat.

Hasil penelitian mendukung teori yang disampaikan oleh Robbins (2014) bahwa kemampuan adalah suatu kapasitas individu untuk mengerjakan berbagai tugas dalam suatu pekerjaan. Selanjutnya totalitas kemampuan dari seseorang individu pada hakekatnya tersusun dari dua perangkat faktor, yakni kemampuan intelektual dan kemampuan fisik. Kemampuan kerja seorang pegawai dapat dilihat dari pengetahuan yang dimiliki oleh pegawai, apabila pegawai memiliki pengetahuan yang tinggi maka kemampuan kerjanya dalam menyelesaikan pekerjaan juga lebih tinggi dari pegawai yang lainnya. Hasil penelitian ini juga sejalan dengan penelitian terdahulu yang dilakukan oleh Afifi, dkk. (2015); Herawati \& Arsilenda (2015); Susetyorini (2012); Wijayanto \& Suhendar (2016); dan Yanti, dkk. (2019) bahwa kemampuan kerja ditemukan memiliki pengaruh positif dan signifikan terhadap prestasi kerja.

Penelitian ini juga membuktikan bahwa pengambangan SDM dan kemampuan kerja secara simultan berpengaruh signifikan terhadap prestasi kerjapegawai pada Dinas Perumahan dan Kawasan Permukiman Kabupaten Kaur. Hal tersebut ditunjukkan dengan tingkat signifikansi di bawah 0,05. Pengaruh pengambangan SDM dan kemampuan kerja secara secara bersama-sama terhadap prestasi kerja adalah sebesar $62 \%$, sedangkan sisanya sebesar $38 \%$ dipengaruhi oleh varabel lain yang tidak diteliti di dalam penelitian ini.Variabel pengembangan SDM memiliki pengaruh yang lebih kuat terhadap prestasi kerja pegawai pada Dinas Perumahan dan Kawasan Permukiman Kabupaten Kaur jika dibanding dengan variabel kemampuan kerja.

\section{KESIMPULAN DAN SARAN}

\section{Kesimpulan}

Sebagai organisasi publik yang berfungsi memberikan pelayanan kepada masyarakat, pengembangan SDM dan kemampuan kerja pegawai pada Dinas Perumahan dan Kawasan Permukiman Kabupaten Kaur menjadi hal yang sangat penting. Berdasar hasil penelitian menunjukkan bahwa kedua variabel tersebutmemiliki pengaruh positif dan signifikan terhadapprestasi kerja baik secara parsial maupun simultan. Besar pengaruh kedua variabel tersebut sebesar $62 \%$, sedangkan sisanya dipengaruhi oleh varabel lain yang tidak diteliti di dalam penelitian ini. Variabel pengembangan SDM memiliki pengaruh yang lebih kuat jika dibanding dengan kemampuan kerja terhadap prestasi kerja. 


\section{Saran}

Pengembangan SDM dan kemampuan kerja diketahui telah menunjukkan pengaruh positif dan signifikan terhadap prestasi kerja pegawai pada Dinas Perumahan dan Kawasan Permukiman Kabupaten Kaur. Namun demikian, pendidikan dan pelatihan senantiasa harus terus ditingkatkan dalam upaya pengembangan SDM. Selanjutnya, melalui pendidikan dan pelatihan tersebut, diharapkan dapat meningkatkan kemampuan kerja pegawai terutama dalam hal pemberian pelayanan kepada masyarakat sebagai organisasi publik.

\section{DAFTAR PUSTAKA}

Afifi, Muhammad Dicky., Musadieq, Mochammad Al., dan Nurtjahjono, Gunawan Eko. Pengaruh Kemampuan Kerja dan Motivasi Kerja Terhadap Prestasi Kerja (Studi pada Karyawan PR. Sejahtera Abadi Malang). Jurnal Administrasi Bisnis. 29(1). 19-25.

As'ad, Moh. 2015. Seri Ilmu SDM: Psikologi Industri. Edisi Keempat. Yogyakarta: Liberty.

Buchari, Zainun. 2016. Manajemen dan Motivasi. Jakarta: Balai Aksara.

Dewi, Citra dan Bendriyanti, Rita Prima. 2019. Manajemen Sumber Daya Manusia. Gorontalo: Ideas Publishing.

Dharma, Agus. 2015. Perilaku Dalam Organisasi. Jakarta: Erlangga.

Laloba, Yostan. 2019. Konsep Pengembangan Sumber Daya Manusia Berbasis Kompetensi, Bakat dan Ketahanan dalam Organisasi. Jurnal Manajemen dan Kewirausahaan. 7(1). 28-35.

Hasibuan, Malayu. 2015. Manajemen Sumber Daya Manusia, Cetakan Kesembilan. Jakarta: PT Bumi Aksara.

Herawati, Heny dan Arsilenda. 2015. Pengaruh Kemampuan Kerja dan Sikap Kerja Terhadap Prestasi Kerja Pegawai pada Badan Pemberdayaan Perempuan dan Perlindungan Anak Provinsi Lampung. Jurnal IImiah Gema Ekonomi. 5(2). 757 764.

Karo-Karo, Sentosa dan Tamami, Sastra. 2016. Pengaruh Pengembangan Sumber Daya Manusia dan Gaya Kepemimpinan Terhadap Kinerja Pegawai Pada Rumah Sakit BP. Batam. Jurnal BENING. 3(1). 87-98.

Krisdianto, Bayu dan Nurhajati. 2017. Pengaruh Pengembangan Sumber Daya Manusia dan Motivasi Terhadap Kinerja Pegawai Dinas Pariwisata Kota Batu. Jurnal IImu Manajemen. II(2). 85-97.

Mangkunegara., Anwar Prabu. 2016. Manajemen Sumber Daya Manusia Perusahaan. Bandung: PT. Remaja Rosdakarya.

Martoyo, Susilo. 2017. Manajemen Sumber Daya Manusia.Edisi Keempat.Cetakan Pertama. Yogyakarta: BPFE.

Nasution, Mulia. 2016. Manajemen Personalia. Jakarta: Djambatan.

Normajatun dan Haliq, Abdullah. 2016. Pengaruh Kemampuan, Motivasi dan Lingkungan Terhadap Prestasi Kerja Pegawai Dinas Perhubungan Komunikasi dan Informatika Kota Banjarmasin. As Siyasah. 1(1). 12-17. 
Nugraha, Rizky. 2016. Pengaruh Pengembangan Sumber Daya Manusia, Disiplin Kerja dan Lingkungan Kerja Terhadap Kinerja Pegawai Pada Inspektorat Kabupaten Morowali. Jurnal Katalogis. 4(10). 176-183.

Prawirosentono, 2013. Manajemen Sumber Daya Manusia. Yogyakarta: Penerbit BPFE

Rachmawati, Ike Kusdyah. 2015. Manajemen Sumber Daya Manusia. Jakarta: Andi Offset.

Robbins, Stephen. P. 2014.Perilaku Organisasi (alih bahasa Drs. Benjamin Molan), Edisi Bahasa Indonesia, Klaten: PT. Intan Sejati.

Saragi, Siswati. 2018. Pengaruh Pengembangan Sumber Daya Manusia Terhadap Prestasi Kerja Pegawai di Kantor Camat Mazino (Kecamatan Mazino Kabupaten Nias Selatan). Jurnal Publik Reform UNDHAR MEDAN. III(1). 97149.

Silalahi, Berneth. 2015. Manajemen Sumberdaya Manusia.Jakarta: Sekolah Tinggi IImu Manajemen LPMI.

Sugiyono. 2013. Metode Penelitian Kunatitatif Kualitatif dan R\&D. Bandung: Alfabeta.

Susetyorini, Horas. 2012. Pengaruh Kemampuan Kerja Terhadap Prestasi Kerja Supervisor PT. Swabina Gatra Gresik. Gema Ekonomi. 1(2). 138-158.

Sutrisno, H. Edy. 2006. Pengaruh Pengembangan SDM dan Kepribadian terhadap Kompetensi dan Prestasi Kerja Karyawan Pada PT. Barata Indonesia di Gresik. Ekuitas. 12(4). 455-475.

Sutrisno, Edi. 2009. Manajemen Sumber Daya Manusia. Edisi pertama. Jakarta: Kencana Prenada Media Group.

Sutrisno, Edi. 2014. Budaya Organisasi. Jakarta: KencanaPranada Media Group.

Suwatno \& Priansa, D. 2011. Manajemen SDM dalam organisasi Publik dan Bisnis. Bandung: Alfabeta

Tarigan, Christoper Giovani dan Nasution, M. Arif. 2014. Pengaruh Pengembangan Sumber Daya Manusia Terhadap Kinerja Karyawan Pada PT. PLN Cabang Binjai. Jurnal Administrasi Publik. 2(2). 146-153.

Tohardi, Ahmad. 2014. Manajemen Sumber Daya Manusia.Cetakan Pertama, Bandung: Mandar Maju.

Wijayanto, Hendra dan Suhendar. 2016. Pengaruh Kemampuan dan Loyalitas Kerja Terhadap Prestasi Kerja Pegawai di Kantor Kelurahan Kebon Bawang di Jakarta Utara. The Indonesian Journal of Public Administration. 2(2). 50-64.

Yanti, Budi., Afriani, Hasna., dan Febriani. 2019. Pengaruh Kemampuan Kerja dan Motivasi Kerja Terhadap Prestasi Kerja (Studi pada Karyawan PT Wahana Wirawan Riau). Jurnal Manajemen dan Kewirausahaan. 10(3). 48-59.

Yusran, Ahmad. 2018. Analisis Pengaruh Pengembangan Sumber Daya Manusia Terhadap Kinerja Karyawan Pada PT. Bank BNI Cabang Utama Kendari. Jurnal Ilmu Manajemen. 4(3). 1-11. 